\title{
Rereading Psalm 121 in an African (Yoruba) context
}

\author{
Peter Olanrewaju Awojobi
}

\author{
Department of Religions, History \& Heritage Studies, Kwara State University, Malete, Kwara State, Nigeria. \\ Email: paawojobi@yahoo.com/peterawojobi@gmail.com; Tel: +234 8033798379.
}

Copyright (C) 2021 Awojobi. This article remains permanently open access under the terms of the Creative Commons Attribution License 4.0, which permits unrestricted use, distribution, and reproduction in any medium, provided the original work is properly cited.

Received 5th June 2021; Accepted 26th June, 202

\begin{abstract}
This article is an attempt to reread Psalm 121 in an African context with reference to the culture of the Yoruba people of Nigeria. The study considers certain Eurocentric interpretation of the Book of Psalms which Africans maintained do not meet their social, physical and spiritual aspirations. An African interpretation of the Bible is an interpretation which adopts the African world view. In this study, Psalm 121 is interpreted in the light of help and protection which are the greatest needs of the African people. The study adopts the African Biblical Hermeneutics. The central focus of this approach is to provide a useful lens to reread biblical text in African context. It was discovered that as early as the third century Christian era, worshippers in the temple chanted, and sung on a regular basis from Psalms. The Psalms were popular in the fourth century with the rise of monasticism as monks chanted the psalms as daily prayer not only for personal guidance but also for spiritual warfare against demons. The ancient Israelites who were the original authors of the Psalter wrote from their experiences. Many biblical scholars and members of African indigenous churches in Nigeria, see the Psalter as divine and potent words. Psalm 121 can be used to invoke help and protection on those who desire them in the same way as words of incantation (ogede) are used among the Yoruba ethnic group of Nigeria. It is hoped that the Psalms and the entire Bible will be properly contextualized to address the challenges that Africans are currently facing.
\end{abstract}

Keywords: African, Eurocentric, hermeneutics, indigenous churches, Nigeria, Psalms, Yoruba.

\section{INTRODUCTION}

Majority of the African biblical scholars today are beneficiaries of the Western biblical interpretation as a result of access to Western education, they are not passive receivers of Western biblical interpretation. Studies revealed that many of the Western biblical interpretations and theologies nourished in the Western intellectualist context cannot produce the desired result in the African communities (Adamo, 2005b: 3). To the Africans, a biblical interpretation is relevant only if it helps Africans to address their concerns. In other words, biblical studies must be relevant to the cultural and religious situation of the community that produced it. The imposition of Western biblical interpretation and values on indigenous African systems is a major setback for mainline churches in Africa. The concern of the African biblical interpreters is on the community that received the text rather than the one that produced it (Ukpong, 1999). An attempt is made in this paper to present how the African indigenous churches have been able to resolve the hermeneutical difficulties created by the Western missionaries by bringing the
African value system of traditional religion into their interpretation of the Bible and Christianity using Psalm 121 as a text of reference.

According to West (2003: 6-10), there are three modes of reading a biblical text. These are reading behind the text", the text itself and "in front of the text". The first mode concentrates on what is "behind the text" of the Bible because it is primarily interested in the historical and sociological world that lies behind the text and from which the text came. The second mode emphasizes the text of the Bible because it was primarily interested in the literary world of the "text itself". And the third mode of reading emphasizes what is in front of the text of the Bible because it was primarily interested in the major metaphors, themes and symbols that are projected by the text. To buttress this, Adamo (2005b: 3) and Ukpong (1999: 2) submit that, it is therefore; very remarkable that African biblical scholars have tried to forge a biblical interpretation strategy that is significantly different from that of the Western interpretation. They believe that Africans must 
read the Bible with their own "eye". Adamo strongly emphasized this when he said: "African cultural hermeneutics is rereading the scripture from a premeditatedly Afrocentric perspective" (Adamo, 2005a: 8). He opined that, "this is a methodology that reappraises ancient biblical tradition and African worldview, culture and life experience..." (Adamo, 2005a: 9-10). In this study Psalm 121 is interpreted in the light of help and protection which are the greatest needs of the African people using the African biblical Hermeneutics.

\section{THE TEXT IN ENGLISH AND HEBREW LANGUAGE}

Psalm 121: ${ }^{1}$ A Song of Ascents. I lift up my eyes to the hills. From whence does my help come?

${ }^{2} \mathrm{My}$ help comes from the LORD, who made heaven and earth.

${ }^{3} \mathrm{He}$ will not let your foot be moved, he who keeps you will not slumber.

${ }^{4}$ Behold, he who keeps Israel will neither slumber nor sleep.

${ }^{5}$ The LORD is your keeper; the LORD is your shade on your right hand.

${ }^{6}$ The sun shall not smite you by day, nor the moon by night. ${ }^{7}$ The LORD will keep you from all evil; he will keep your life.

${ }^{8}$ The LORD will keep your going out and your coming in from this time forth and for evermore.

(Psa 121:1 RSV)

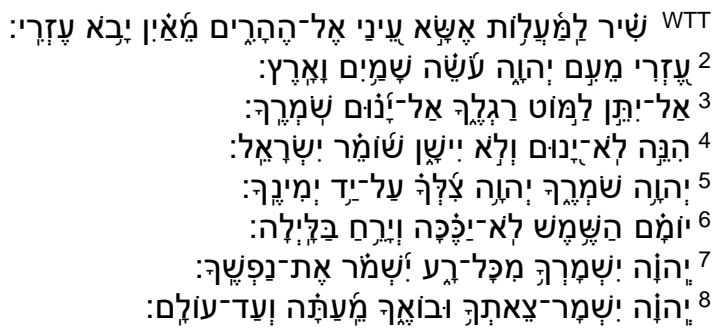

\section{LITERARY ANALYSIS OF PSALM 121}

This Psalm is one of the fifteen "Songs of Ascents" (cf Psa 120-134). Some scholars maintain that this Psalm may have been chanted by pilgrims ascending to Jerusalem (Payne, 1987: 835) and can be divided into two parts: the Lord is the Creator who is the helper (vv1-2), the Lord is the security/guardian of Israel (vv 3-8). The Psalmist is looking with great anxiety to the hills or mountains in his search for assistance because true help can come only from the God who made the mountains (vv1-2). The physical reality of mountains led to their use as a metaphor for refuge in biblical literature (Psa.11:1; Ezek. 7: 16; Hos 10:8). A metaphor is 'using something to be something else which is obviously and literally not' (Mays, 1994:112-
119). It does not describe by comparison but only identifies by equation (Mays, 1994:115-119). Mountains also represent large obstacles, or physical boundaries between Israel and her neighbors (Isa 40:4; 49: 11; cf. Zech 4:7). A unique personal description of a mountain as a symbol of inner strength and security may be present in Psa 30:7, 8.

In ancient Israel, places of worship were located on the mountains. The prophets in the Old Testament often express the idea that God's mountain will ultimately be supreme over all. For instance, Daniel described the kingdom of God as a mountain created without human interference (Dan 2: 35, 44-45). Many of the central features of the Old Testament's hope will take place at Zion, which will be restored to its true role as "the Holy Mountain" (Zech 8:3). There Yahweh will reign (Isa 24:23), because Zion is the place where God will achieve final victory over his enemies (Ezek 38-39; Zech 14: 3-4), celebrate his final banquet (Isa 25:6), and abolish death (Isa 25:7). (VanGemeren, 1997: 1053- 1054).

The Psalmist in verse 2 declared that "my help comes from the Lord, who made heaven and earth". This suggests that the Psalmist is longing for protection, guidance, and blessing which can only come from the Lord who is the maker of heaven and earth. This is an indication that the Psalmist acknowledges the sovereignty of Yahweh over all realms and gods (Baker and Kohlenberger, 1994: 920).

In verses 3-6, the Psalmist attested to the guardian of Yahweh over Israel. The expression "he will not suffer your feet to be moved" suggests absolute trust and confidence in Yahweh. According to Goulder; it is more likely that the singer is a national leader of ancient Israel, possibly a king that trusts in Yahweh (2006: 463-473). It is clear that the motif of trust is dominant. Goldingay agreed with Goulder when he asserted that it is a 'psalm of trust' (2006: 334355). The grounds for the Psalmist confidence lies in the development of the doctrine of God: the guardian of humans. God protects, guides, and blesses his own. The intensity of his care and concern is further amplified as 'he never sleeps nor slumbers'. The Psalmist therefore informed his audience that the Lord will be their "shade" as he protects them day and night. The Lord is always there to help and to protect his people. In the same vein, Brueggemann, classified this Psalm as a Psalm of Confidence or Trust (1984:154). He went further to describe the Psalm as a life of trustful receptivity of God's gifts (1984:154). The author uses pronouns and names like several other Psalms, and the presence of God transforms everything. This was supported by Kraus (1988:305) who opined that this Psalm belongs to the form of prayer songs which Gunkel considers as songs of trust (Clifford, 2002:130-133).

Verses 7-8 expresses God's blessing and preservation. The expression "the Lord shall preserve you from all evil" is an indication of absolute protection from all harms. It guaranteed divine security for the Psalmist from any form of evil. The Lord's care extends to all adversaries as he 
superintendent over all affairs of humans as travelling mercies are guaranteed (Baker and Kohlenberger, 1994).

\section{INTERPRETATION OF PSALM 121}

This section is an attempt to critically consider Psalm 121 with the aim of understanding the original intention of the author. This Psalm is a Song of Ascents and some scholars agreed that it enjoyed literary dependent on priestly benediction (VanGemeren, 1997: 761). As mentioned earlier, it is a Psalm of confidence and trust in Yahweh.

In verse 1, the phrase: "I will lift up my eyes to the hills" suggests that the Psalmist is searching for assistance. It appears his head is bow down in grieve or anguish, confused as all expectations are cut off. The verb "to lift up" אתֵָׁنא is Qal verb imperfect first person common singular and used 655 times in the Old Testament (TWOT 1421; BDB 6337, p. 669; Strong 4984, 5375, 5379). It is used almost six hundred times with basically three separate meanings: "to lift up"; "to bear, carry, support"; and "to take, take away." This verb is used both literally and figuratively. For instance, "to lift up one's head" in restoration to honor and glory (Gen $40: 13,20)$. It is also used in showing cheerfulness and independence (Job 10:15; Zech 2:4; Psa 83:3). Figuratively, it is used for the lintels of the gates of the city (Psa 24:7, 9)? Also, "to lift up one's face or countenance" as an indication of a good conscience, confidence, favor, or acceptance (2Sam 2:22). "To lift up the eyes" often before verbs of looking or seeing (Gen 13:10, 14), in love or desire to men (Gen 39:7), towards God (Psa 123:1), and to an idol (Ezek 18:6, $12,15)$.

It should be noted that the Hebrew word Semitic term meaning "eye" or "source" (TWOT, 1612; ISBE Dictionary 3302). Occasionally, it represents the whole process of seeing and by extension of understanding and obedience (Jer 5:21). The eye is used to express knowledge, character, attitude, inclination, opinion, passion, and response. The eye is a good barometer of the inner thoughts of man. Of all the physical organs of the body, the eye was considered as one of the more important parts. In this context the author is looking unto God for mercy in his life. It may probably have been a time of trouble for him and he needed divine intervention.

The Hebrew word רhill appeared 61 times in the Old Testament, hill country (once) mount, mountain 486 times (TWOT 517a; ISBE 4336). The antiquity, majesty, power and height of mountains reaching up to the heavens above the clouds naturally led people to associate mountains with gods. Mountain could be described as a unique symbol of inner strength and security. Moses and Elijah prayed on a mountain (Exo 17:9; 1Kings 18:42); blessings and curses are invoked from Mount Ebal and Gerizim (Deut 11:29; Deut 27:12ff; Josh 8:33), worship is offered on various mountains (cf. Gen 22:2; Josh 5:3; 1Sam 9:12ff; 1Kings
3:4) and the ark is set on a hill (1Sam 7:1; 2Sam 6:3). These are indications that ancient Israelites regarded the mountains as the abode of Yahweh.

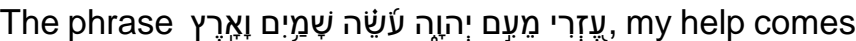
from the LORD, who made heaven and earth. The God of Israel is referred to here as the "maker of heaven and earth" or the creator of the universe and as such the Psalmist is looking up to him (Gen. 1:1; Ps 115: 15; Prov. 3: 19-20). עִ means help, support, helper (TWOT 1598b, BDB 6971, Strong 5826). In this context, it designates divine assistance both material and spiritual. With the sense of that which brings aid, support, or deliverance, "help" represents a large variety of words in Hebrew (VanGemeren, 1997: 378). A principal Hebrew word is the Hebrew word עָז ,"to help," with the corresponding nouns עִ . True help is to be sought for in Yahweh, in whom, believer is constantly exhorted to trust absolutely (Psa $20: 2 ; \quad 33: 20 ; 42: 5 ; 46: 1 ; 115: 9,10,11 ; 121: 2$; Isa $41: 10,13,14$, etc.) (Holladay 6205, ISBE 4243).

Another phase that must be underscored in our study is "He will not let your foot be moved, he who keeps you will

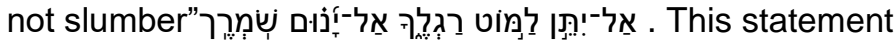
is an assurance of Yahweh's sustaining care for the purpose of preserving the lives of his people. The Hebrew word רִ means foot especially of humans as in the case of Ezekiel's prophetic vision (Ezek 1: 7ff) to the seraphim (Isa 6:2), and cherubim (2Chr 3:13). The word is a feminine noun, found in Hebrew, Aramaic, and some later Semitic and it appears 245 times in the Old Testament. In this context, the Psalmist maintained that Yahweh will ensure that the foot of those who trust in him is not shaken. It is used as an assurance of Yahweh's sustaining care for his people (Psa 66: 9; cf. 55: 22-23). It means that if the foot of the righteous were to slip, Yahweh's steadfast love would sustain such a person (VanGemeren, 1997: 865). It should be noted that this same word is used for carrying poles or a yoke. The connection between slipping and shaking and carrying poles is probably because of the back and forth, up and down shaking motion of the poles when used for transport. The Psalmist assured his readers that Yahweh is not a man that could slumber. Yahweh is always awake and active all the time.

Furthermore, the Psalmist declared: "behold, He who

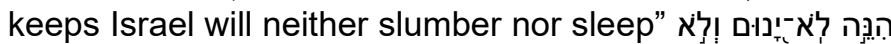
The word "behold" suggests that the Psalmist is calling the attention of his audience to what is glaring and tangible. To him, it is what everyone can see. The keeper of Israel does not sleep nor slumber as evident by his activities among them. Yahweh does not sleep like humans or other gods as claimed by Elijah (1 Kgs. 18: 27) (VanGemeren, 1997: 554). However, when Yahweh appears to be far off in time of need, He may be described as sleeping (Psa 44:23-24; cf. 132: 4) and as waking when he renews his attention to the problem (78:65). The author of this Psalm is using sleep metaphorically, to refer to a perceived sense of inexplicable divine inactivity. Sleep was a quality ascribed to pagan gods, e.g. Elijah's taunt 
concerning Baal's being asleep (1Kings 18:27). In contrast, the Psalmist says concerning Yahweh, "He who keeps Israel will neither slumber nor sleep". Amidst a polytheistic environment this confession possessed dramatic content.

Also, the clause: "the LORD is your shade"הצֵֶּ suggests protection from all forms of adverse climatic situations. One of the attributes of Yahweh over the years is protection. Yahweh is believed to be concern with the security of his people. In this verse the Psalmist see God as a "shade" or shadow. A shade is a place a person under the heat of the sun can take cover. The Hebrew word shadow, conveys the ideas of shade, protection, and defense. Shade, even that of a boulder, gives some relief from the heat of the day, especially for the slave (cf. Job 7:2). The statement: "under the shadow of one's roof" connotes that the head of the house provides protection for his guests (Gen 19:8, ASV). Yahweh is the shade or the source of protection for his people (Psa 121:5ff; Isa 25:4). Therefore, the Psalmist prays that God may hide him under "the shadow of his wings" (Psa 17:8; cf. Psa 36:7, 8; Psa 91:1).

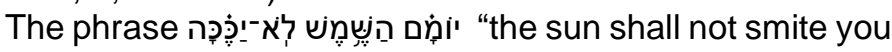
by day". The sun is believed to have power. It could strike a man and cause him to faint (Jon $4: 8$ ). The Hebrew word dשֶֶׁׁ (shemesh) sun appears 131 times in the Old Testament. The sun is used to designate time and direction; its rising equals the east and its setting the west (Zech 8:7). However, the Lord protected the pilgrims from the sun's striking (Psa 121:5, 6) (VanGemeren, 1997: 175). More frequently the sun was considered a blessing. It helps the fields bring forth rich crops (Deut 33:14). A just ruler is "like the sun shining forth upon a cloudless morning" (2Sam 23:4). The Lord himself is compared to the sun due to the fact he brings warmth and prosperity to the believer's life; "the Lord God is a sun and shield; he bestows favor and honor" (Psa 84:11,12). Since the sun survives the generations, it stands as a sign of longevity, e.g. for the enduring throne of David (Psa 89:36,37).

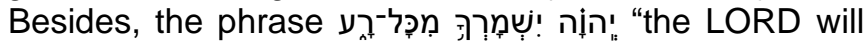
keep you from all evil" is an indication that God does not want evil to befall his people. In biblical creation account, we saw that when God created heaven and earth and both were very good (Gen. 1: 31). The basic Hebrew word for evil is רָער.This word also means bad, misery, distress, injury, wickedness. The feminine noun רָ functions much like the masculine adjective, though somewhat more frequently. Often רָָָ is an adjective too, and qualifies its nouns in terms of the negative function, or condition, and the injurious activity of the noun. God's own character and attitude measures the value of things and people (2Kings 8:12 Jer 29:11; cf. Jon 4:2, 6).

To assure his audience of God's protection, the Psalmist

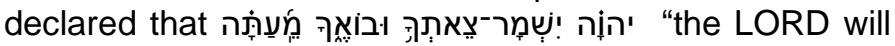
keep your going out and your coming in from this time forth and for evermore". Here in this verse, the Psalmist informed his hearers that their continuous security is guaranteed in Yahweh (VanGemeren, 1997: 644). The Hebrew word ע forever, everlasting, evermore, perpetual, old, ancient, world, always, eternity and so on is used more than three hundred times to indicate indefinite continuance into the very distant future, the meaning of the word is not confined to the future. There are at least twenty instances where it clearly refers to the past. Such usages generally point to something that seems long ago, but rarely if ever refer to a limitless past. Thus, in Deut 32:7 and Job 22:15, it may refer to the time of one's elders. In Prov 22:28; Prov 23:10; Jer 6:16; Jer 18:15; Jer 28:8 it points back somewhat farther. In Isa $58: 12$; Isa $61: 4$; Mic 7:14; Mal 3:4, and in the Aramaic of Ezr 4:15, 19 it clearly refers to the time just before the exile. In 1Sam 27:8, Isa $51: 9$ and Isa 63:9, 11 and perhaps Ezek 36:2, it refers to the events of the exodus from Egypt. In Gen 6:4, it points to the time shortly before the flood. None of these past references has in it the idea of endlessness or limitlessness, but each point to a time long before the immediate knowledge of those living.

\section{READING PSALM 121 IN AFRICAN (YORUBA) CONTEXT}

According to Adamo, one of the basic characteristics of African Biblical Hermeneutics is that it is highly existential in its interpretation (Adamo, 2015b: 31-52). He went further to assert that the main aim of African biblical interpreters is to bring real-life interest into the text for a better interpretation and understanding of the text under consideration. Such life interest may be security, provision, and protection, which are the major concerns of Africans. The African biblical interpreter is not keenly interested in the historical, social and literary dimensions of the text but how the text can meet the felt needs or challenges of the African people (Adamo, 2015b: 31-52). As mentioned earlier, the African mode of reading is what West called "reading in front of the text". This mode of reading is primarily interested in the major metaphors, themes and symbols that are projected by the text (West, 2003: 6-10). In other words, it is a reading that makes the text relevant in any culture and traditions.

To this end, Psalm 121 is classified by scholars as a Psalm of help and security/protection and will be interpreted in that context (Adamo, 2015b: 52). The structure of Psalm 121 in the African context is classified according to African real-life interest and how it can be applied to the challenges confronting the readers especially in terms of help, and protection. To the African indigenous churches, Psalm 121 is a psalm for protection and help from the God of creation. This view appears to be in line with the way the Psalm was used in ancient Israel as attested by archaeological discoveries from the first millennium with the verbs שמר [guard] and נצר [protect] inscribed on them (Schmitz, 2002:818-822; Smoak, 2010: 421-432, 2011:75-92). These verbs as found in ancient 
documents and Psalms to a large extent are indications of some common cultural and religious practices on the issue of security and help as provided by Yahweh. Brown attested to the fact that Psalms are performative when used orally, chanted and recited as divine prayers by the Christian church as early as the third-century Christian era not only for guidance but also to drive away demons (Brown, 2014). Psalms are like the trends in modern speech act theory (Nasuti, 2001:144) which maintains that words are potent and effective.

It should be noted that protection is a global concern but is more critical to the Africans who are faced with life threatening situations on a daily basis. The level of insecurity, violence, injustice, poverty, sickness and fear is on the increase when compared to that of the Western world. Psalm 121 would now be discussed in African context thus:

1. Help - vss. 1 \& 2

2. Protection - vss. $3,4,5,6,7 \& 8$

\section{Help (vss. 1 \& 2)}

The Psalmist in verse 1 declared his intention for calling on God when he said: "I lift up my eyes to the hills. From whence does my help come?" This pronouncement from the author suggested that he was in critical situation and that he needed urgent attention and intervention. It is important to understand the African perspective of help before attempting to interpret the text. Africans are always faced with situations that are beyond their control. The level of poverty, insecurity and health issues are very high in Africa. There is a popular saying that no man is an island on his own. Everyone needs the help of one another. In the biblical literature, we are told that God created Eve to serve as a helper to Adam (Gen. 2: 15- 25). Everyone at one time or the other needs assistance. The Yoruba phrase: "Emi yogbeoju mi sioriokewonni", "I will lift up my eye to the hill" suggests that the speaker is looking for assistance from the person in or on the hill. In African tradition, some hills or mountains are believed to be sacred. Some mountains and hills are dedicated to the worship of some deities/gods. It is common to see Africans on the mountains or hills offering sacrifices to the gods they believe live in or on the mountains. In my town Share in Ifelodun local Government Area of Kwara State Nigeria for example, the Chief Masquerade "Egungun" will always come from the mountain to bless the people during the annual Egungun festival. The Egungun is called Ara Orun (the one from heaven). The Egungun is believed to be a messenger of the gods. His advent connotes divine presence. The Egungun delivers the message of the gods to the people (Baba, 2020: 67). When the Psalmist said: 'I will lift up my eyes to the mountains'. This reminds an average African of the gods who resides on the mountains (Baba, 2020: 74). Mountains were like cities of refuge for the African people during the intertribal wars. There are stories of how people relocated from the valley to the mountains in the events of war to fight their enemies. Some African communities are still located on mountain top till today decade after the wars have ended (Baba, 2020: 19).

Among the African Indigenous churches, mountains or hills are good places of prayer. Some Christian faithful spend days or weeks on the mountains to seek the face of God on issues of concern in their lives. Some prayer mountains are named after their founders. For instance, Ori Oke Babalola (Mountain of Babalola) at Odo-owa, Kwara State, Nigeria was named after its founder Prophet Ayodele Babalola of Christ Apostolic Church (Medaiyese, 1950: 3). People from all walks of life with differs needs do go to this mountain to call the God of Ayodele Babalola to come and help them. Orimolade established the practice of going to the mountain to pray and wait upon God to enable a person leave his or her immediate and noisy environment to a more sanctified and reserved place where he would be able to cultivate solitude and the presence of God (Idowu, 2009: 221). The founders of indigenous churches in Africa were found praying or holding special programs designed to meet the felt needs of the people on the mountains as the need arises. Today, virtually every denomination in Nigeria now has a camp, recreation centers, monasteries and so on for retreats and private time with God and most Christian faithful have visited a camp or mountain at least once for prayers. For instance, the Redeemed Christian Church of God (RCCG) has camp called the Redemption Camp at Lagos Ibadan Express Way. The Deeper Life Bible Church has a camp in Ayobo, Lagos and all over 36 states in Nigeria. Some churches are built on mountains by leaders of African indigenous churches. In fact, because of the importance they attach to mountains as it relates to divine presence and prayer. The church buildings on land or valley are also called mountains. For instance, a church building in a city or town may be called mountain of salvation (Oke lgbala), Oke lbukun (mountain of blessing), Oke-lyanu (mountain of miracle), Oke-Itusile (mountain of deliverance), OkeIrapada (mountain redemption), Oke-Isegun (mountain of victory) and so on. Also, the Pastor of most indigenous churches like Christ Apostolic Church (CAC) are called Baba Ori- Oke (Father on the Mountain). All this is because of the view that the presence of God is felt on the mountains. In the Old Testament, Moses was said to have received the Law from God on the mountain (Exod. 20). Some remarkable events in the Bible took place on the mountains. It should be noted however, that the Psalmist and the Christian faithful in Africa are not seeking help from the mountains but from God who lives in or on the mountains.

This is confirmed by the next verse that says: "my help comes from the Lord, who made heaven and earth". "Iranlowo mi yio ti owo Oluwa wa, ti o da orun on aiye". In this context, the Psalmist is seeking the help of Yahweh on 
the challenges confronting him. As mentioned earlier, after the creation of Man, God observed that he needed help and as such God created Eve as his helper (Gen. 2). Eve is God's help to Adam. Yahweh's help is required in the journey of life. This is an indication that no man is an Island on his own. At a particular time in life everyone needs help. To the Psalmist, the sure help is from the Lord who made heaven and earth.

In African context, help is an essential commodity. It is held that God will send humans to help in times of needs. The communal setting of Africa is an indication that assistance is expected from one another. Africans live together in immediate family, extended family, clans, ethnic groups, and so on. They share their success, failures, challenges and pains together (Adamo, 2005b: 81). The communal spirit reflects in all that the Africans do. For instance, in farming, some farmers may come together as a group. They work in the farm of member group to till the ground, plant seeds, hoeing and harvesting of crops planted. This effort has made the dreams of many to be fulfilled.

\section{Protection (vss. 3-8)}

All over the world, people are concerned with protection. In Africa especially, people are concerned with protection of lives and property. The process of protection by African indigenous people is remarkably different from that of the Western world because of the peculiar perception of their worldview. To an average African, humans are very wicked. This agrees with the Bible's description of man when it says: "the heart is deceitful above all things and desperately wicked...." (Jer. 17:9). Africans have device different means of tackling security issues in the continent.

The Psalmist declared in verse 3: "He will not let your foot be moved, he who keeps you will not slumber" (On ki yio je ki ese re ki o ye; eniti npa o mo ki yio togbe). The phrase "He will not let your foot to be moved" (On ki yio je ki ese re ki o ye) is very important. The Psalmist recognizes the protection of God on his people as not negotiable. He is convinced beyond any reasonable doubt that God's protection for his people is guaranteed. The Hebrew word vin is a verb, which occurs as a figure of speech referring to great insecurity, can also denote dependability and certainty when used of God.

When טiמ in is used with "foot," (ese) it speaks of the foot slipping or sliding in a time of calamity (Deut 32:35; Psa 38:16, 17; Psa 94:18). In Psa 82:5, this verb depicts general disorder on the earth: "all the foundations of the earth are slipping." But those on the side of the Lord are unmovable and secure, for they have the Lord as their rock and salvation (Psa 62:2, 3, Psa 62:6, 7; Psa 112:6; Psa 15:5; Psa 16:8; Psa 21:7,8; Psa 30:6, 7). God gives them a hand on the pathway of life so that their footing does not slip (Psa 17:5). The enemy of the righteous will have no cause to rejoice in his being moved (Psa 13:4, 5), for he trusts in the salvation of God.

Among the Africans, "foot" is very import. The Yoruba in Western Nigeria call foot ese. To the Yoruba, everyone uses ese to walk into divine destiny. Foot is a vehicle through which a person rises and falls. For the assurance that God will prevent the foot of the one who trust in him from falling is a great thing. Some Africans belief that there are good and bad foot. For instance, when a woman is married and her husband who was doing well before the marriage started going down, it will be said that the wife has bad leg. She may be required to do some purification of the legs for her to be a suitable wife.

Furthermore, the phrase "he who keeps Israel will neither slumber nor sleep" (eniti npa Israeli mo, ki itogbe, beni ki isun) is very important to the Africans because of high level of insecurity of life and property. In the event of danger, some Africans call on their parents who are dead to deliver them. To the African indigenous people, a dead ancestor is still in the business of protecting his or her children (Adamo, 2005a: 13). That is why in the face of evil or danger, the living members of the family call on dead parents or relations for intervention. When people are going through tough time they sometime say: lya mi ma sun lorun o (my mother, do not sleep in heaven), Baba mi lorun mase sun (my father in heaven do not sleep). This is because they believe that the dead parents still see what is happening on earth and can render help. It is good news to a neither African Christian to hear that the one who keeps him does not sleep nor slumber.

In some part of Africa, people cannot sleep with their two eyes closed. In the north eastern part of Nigeria, the activities of Boko Haram insurgency pose a great threat to people's lives and property. Hundreds of people have been killed or displaced by this group. Also, those who have money to engage the services of security guards in Nigeria today are not safe because security can be compromised or the guards killed on duty by robbers. Sometimes the human security guards may sleep on duty and by so doing endanger the lives of the persons they are employed to guard but the God of Israel does not slumber nor sleep. He is actively on duty daily.

The word צֵ" shadow" (ojiji) conveys the ideas of shade, protection, and defense. Shade, gives some relief from the heat of the day, especially for the slave (cf. Job 7:2). "Under the shadow of one's roof" connotes that the head of the house provides protection for his guests (Gen 19:8). This is very important to an average African because of the hotness of the sun especially in the day time. God is portrayed in this verse as the one who can provide shade even when the weather is hostile. Yahweh is the shade or the source of protection for his people (Psa 121:5ff; Isa 25:4). Therefore, the Psalmist prays that God may hide him under "the shadow of his wings" (Psa 17:8; cf. Psa 36:7, 8; Psa 91:1).

Besides, the phrase "the sun shall not smite you by day" (Orun ki yio pa o nigba osan, tabi osupa nigba oru) should be noted. The sun provides light in the day for humans. 
Integ. J. Arts and Human.

The Africans experience great heat from the sun in the afternoon almost on a daily basis. A man with roof over his head cannot be smitten by the sun. As far as an average African is concerned, protection from the heat of the sun is a great thing. Africans understand what it means to be smitten by the sun. It is good news for them to hear that God shall deliver them from being smitten by the sun.

Moreover, the phrase "the LORD will keep you from all evil; He will keep your life" (Oluwa yio pa o mo kuro ninu ibi gbogbo: yio pa okan re mo) is an important one to the Africans who believe that they are constantly surrounded by evil men and women. For instance, the Yoruba people of south west Nigeria believe that every person has at least an enemy called ota. According to them there are two types of ota (Adamo, 2005b: 70). The first is as a result of quarrels, disputes, inheritance or property, chieftaincy matters, rivalry in polygamous homes and the likes. The second is called Aye (the world). These are sorcerers, witches, wizards and all persons that are wicked. They employ various techniques in harming the enemies (Adamo, 2005b: 70). According to Dopamu and Madarikan (1987: 58), they use potent words called incantations (ofo) pronounced on charms (epe) on their enemies. The effects of this on the so called enemies may be abnormal behavior, death, loss of property, sickness, poverty, loss of job, ill luck, demotion and all sort of evil.

Evil is so real and feared by the Africans that before the advent of Christianity they have devised several ways or methods to tackle it. Africans had a cultural way of dealing with the problem of enemies and evil doers. One of the cultural ways of dealing with the problem of evil or enemies is the use of incantations called ogede in Yoruba language for defense. According to Adamo: "the existence of evil, witches and sorcerers are painfully real. In African tradition, all means are used to protect children, young, and adult. These include the use of animate and inanimate things, such as stones, sand, trees, leaves, human parts, animals, water, urine, and whatever can be mentioned" (2005:69) Through these, protection of lives and property was achieved by them.

It should be noted that some eminent biblical scholars (E. Jacob, W. Eichrodt, O. Prockesh, G. von Rad, G.A.F. Knight and R. Bultmann) would appear to agree with African biblical scholars that the spoken word in ancient Israel was 'never an empty sound but an operative reality whose action cannot be hindered once it has been pronounced' (Eichrodt, 1967:69; Jacob, 1958:127; Knight, 1953:14-16; Von Rad, 1965: 85). This is the reason why some Jews in ancient Israel wrote the words of the scripture especially Psalms on their bodies, singing and chanting these words in their daily meditations and prayers to Yahweh.

However, during the advent of Christianity in Nigeria, Christians were asked to abandon these methods of protection (Adamo, 2005b: 77). It was in search for an alternative source of protection that the converts to Christianity discovered in the Bible, the book of Psalms, whose words resemble their incantations. Thus, the Bible became a substitute. Psalms 13, 46, 91,116, 121, 125 and Job 5: $18-27$ are used for protection. The Bible, particularly the Psalms, become the talisman or amulets, medicine, potent words (so-called incantations) for protection, healing, provision and enhancing success when inscribed on parchments, bodies, vehicles, doorposts and recited, chanted and sung with unwavering faith or trust in God (Adamo, 2005b: 78).

The phrase "the Lord will keep your going out and your coming in" (Oluwa yio pa alo ati abo re mo) should be noted. This is very important to an average African because of the condition of the roads on which they travel on a daily basis. Most African roads are nothing but death trap. Most wealthy people in Nigeria for instance, prefer to use the air (Aero plane) for travelling than roads not because it is faster but for safety purposes. The rate of accidents on Nigerian roads is very high. Several people have been killed on our roads. The roads are so deplorable that a journey of one hour can take five hours. Besides, kidnappers are found along most roads in Nigeria today. Whenever people are kidnapped, the kidnappers raped and assault their victims in many ways. The kidnappers request a huge amount of money as ransom from relations or friends of their victims before they are released. Those who have no money to pay are killed or sometimes people who paid are molested and killed. In the northern part of Nigeria, the activities of bandits are very prominent. Recently, Bandits abducted over 300 students from a secondary school in Kankara, Katsina State, Nigeria (Owojaiye, 2020). It took the intervention of Government and some security agents before they were released and united with their parents.

\section{CONCLUSION}

From the foregoing, African Christians perceived the Bible to be a special literature that have answers to the questions of humans on help, protection and security, provision, success, sickness, and so on. To the African Christians, the book of Psalms contain potent words that can be used in life threatening situations. Psalm 121 is considered by the African indigenous churches as a Psalm of help and protection in the time of trials and challenges of all sorts. African Christians read, sang, chanted and inscribed this Psalm with a view to be protected on a journey on the road or on a flight or sea or when one is asleep at night to be healed of diseases, for provision at the time of need and to achieve success in life. That is the existential situation in Africa.

Today, many Christians in Africa indigenous churches, Pentecostals and even the Mission established churches repeatedly read, chant and write on their motor vehicles, homes, and doorposts some portion of Psalms or the Bible as a way of reaffirming their faith in God's power to save. One of the things that make the Psalms unique is that it 
has the capacity to situate those who used them in a relationship with God because worshippers feel as if they are the first recipient of the message. As far as the users of Psalms in Africa especially Nigeria are concerned, the Bible, particularly the Psalms, becomes the talisman or amulets, medicine, potent words (so-called incantations) for help and protection when inscribed on parchments, bodies, vehicles, doorposts and recited, chanted and sung with unwavering faith or trust in the Almighty God.

\section{CONFLICT OF INTERESTS}

The author declares no conflict of interests.

\section{REFERENCES}

Adamo, D. T. (2005a). Explorations in African biblical studies. Benin City: Justice Jeco Press \& Publishers Ltd.

Adamo, D. T. (2005b). Reading and interpreting the Bible in African indigenous churches. Benin City: Justice Jeco Press \& Publishers Ltd.

Baba, S. O. Y. (2020). The History and Heritage of Idoba Araromi Community. Ilorin: Amazing Grace Press.

Baker, K. L., \& Kohlenberger III, J. R. (1994). The Expositor's Bible Commentary- Old Testament Grand Rapids: Zondervan.

Brown, W. (2014), 'The Psalms: An overview'. In Brown, W. (ed.). The Oxford handbook of the Psalms (pp. 1-26), Oxford University Press, Oxford.

Brueggemann, W. (1984), The message of the Psalms: A theological commentary. Augsburg, Minneapolis, MN.

Clifford, R.J. (2002). Psalms 1-72. Abingdon Press, Nashville, TN.

Dopamu, A. P., \& Madarikan, O. (1987). The reality of Isaasi, Apeta, Ironsi, and Efun as forces of evil among the Yoruba. Journal of Arabic and Religious Studies, 4, 50-61.

Eichrodt, W. (1967), Theology of the Old Testament II, London: SCM Press.

Goldingay, J. (2006), Psalms: Psalm 1-41. Baker Academic, Grand Rapids, MI.

Goulder, M. (2006). David and Yahweh in Psalms 23 and 24. Journal for the Study of the Old Testament, 30(4), 463-473.
Holladay, W. L. (1993), The Psalms through three thousand years: Prayer book of a cloud of witnesses, Fortress Press, Minneapolis, MN.

Idowu, M. O. (2009). More than a prophet: The adventure of Moses Orimolade Tunolase. Ikeja: Divine Artillery Publications Jacob, E., 1958, Theology of the Old Testament, transl. Heathcoat, A. W. \& Allcock, P. J. (eds.). Harper \& Row, New York.

Knight, G. A. F. (1953). A biblical approach to the doctrine of the trinity. T. \& T. Clark, Edinburgh.

Kraus, H. J. (1988). Psalms 60-150, transl. Oswald, H. C. (ed.). Augsburg, Minneapolis, MN.

Mays, J. L. (1994). Psalms. Interpretation, Westminster/John Knox Press, Louisville, KY.

Medaiyese, J. A. (1950). The autobiography of Babalola. Okene: Alafia-Tayo Printing Press.

Nasuti, N. P. (2001). Historical narrative and identity in the Psalms. Horizon in Biblical Theology, 23(2), 132-153.

Payne, J. Barton, (1987). Psalms, book of. New International Bible Dictionary. Grand Rapids: Zondervan

Schmitz, P. C. (2002). Reconsidering Phoenician inscribed amulet from the vicinity of Tyre. Journal of the American Oriental Society 122, 817-822.

Smoak, J. D. (2010). Amuletic inscriptions and the background of YHWH as guardian and protector in Psalm 12. Vetus Testamentum, 60, 421-432.

Smoak, J. D. (2011). Prayers of petition in the Psalms and West Semitic inscribed amulets: Efficacious words in metal and prayers for protection in biblical literature. Journal for the Study of Old Testament 36(1), 75-92.

Ukpong, J. S. (1999). Can African Old Testament scholarship escape the historical critical approach? Newsletter on African Old Testament Scholarship, 7, 2-5.

VanGemeren, W. A. (1997). New International Dictionary of Old Testament Theology \& Exegesis. Vol. 1-5. Grand Rapids: Zondervan

Von Rad, G. (1965), Old Testament theology, II, T. \& T. Clark, Edinburgh.

West, G. (2003). Contextual Bible Study Pietermaritzburg: Cluster Press. 